\title{
Offenses against the quality of life : What about the responsibility of multinationals?
}

\author{
Nadia Lamchichi ${ }^{1}$, Fatima Zahra El Arif ${ }^{2}$ \\ ${ }^{I}$ PhD student - Center of Doctoral Studies, Faculty of Economic Sciences, University Mohammed V-Souissi, \\ Rabat, Morocco. \\ ${ }^{2}$ PhD student - Center of Doctoral Studies, Faculty of Economic Sciences, University Mohammed V-Souissi, \\ Rabat, Morocco.
}

\begin{abstract}
In the era of sustainable development and the green economy, it has become essential to wonder to what extent the laws applicable to multinationals may include legal standards of environmental protection, putting into question the social and penal responsibility of multinationals. This paper is a modest attempt that fits in this sens.
\end{abstract}

Keywords : Multinationals, Social Responsibility, Penal Responsibility, Law applicable to multinationals.

\section{Introduction}

The environmental protection has long been marginalized. For three decades, water, air, earth are abused and even attacked from all sides and in all forms by economic concentrations that have made the industry the focus of development and wealth. The international legal order reveals the constant challenge between on the one hand, the preservation of the ecology as an essential component of our lives, and secondly, the financial interests of economic powers.

Indeed, the media coverage of major pollution or environmental disasters demonstrates the problems of effective implementation of international environmental law ${ }^{1}$. Among the most famous transnational corporations, most of which were at one time or another publicly denounced for their direct or indirect involvement in violations to the environment. To illustrate this, by way of example and not limitation, the International Federation for Human Rights was able to highlight, through its documentation work endangering the lives of others, through the operation of hazardous waste, the expropriation of indigenous peoples, etc ${ }^{2}$.

In the spirit of sustainable development, the concept of environmental responsibility is related to those social and penal responsability of multinationals. This report highlights the emphasis of environmental offences in developing countries presenting an important factor of discrimination. The principle of the exercise of sovereignty over natural resources in some countries without legal and institutional instruments to deal with lobbyists holdings reveals a double-edged sword. That is why the international legislation has not developed standards or beneficial norms, lack of consensus between the states of the international community.

This paper raises on one hand, questions relating to the ineffectiveness of the norms of international environmental law to better empower legally multinationals (II), and on the other hand, it offers possible solutions to harmonize the collective responsibility of economic groupings with the International Criminal environmental Law (III).

\section{The accessory nature of international environmental law against multinationals}

In essence, the human right to the environment conceived primarily in terms of protection of natural resources is in constant conflict with transnational companies led by financial concerns ${ }^{3}$. With financial globalization, they have gained unprecedented power (example: the case of British Petroleum against the United States).

Several unacceptable damages to the environment that take place in some countries are totally legal. The disparity between ecological domestic legislation involves the transfer of industrial and chemical pollution from developed countries to developing countries. A typical example, pesticides or prohibited fertilizers in rich countries are still used by poor countries to the detriment of the health of exposed populations. The same reasoning applies to the economic strategies of multinationals which adapt themselves according to the nature of

\footnotetext{
${ }^{1}$ London, C., L'environnement, une nouvelle donne économique, Petites affiches n 78, 30 juin 1995, p. 4.

${ }^{2}$ Bernard A., Elin W., La responsabilité pénale des transnationales- L'action de la FIDH, AJ Pénal, 2012, p. 20.

${ }^{3}$ Jegouzou Y., Propriété et environnement, Defrénois n 7,15 avril 1994, p. 449.
} 
advanced environmental regulations or otherwise «mediocre ». It is customary multinationals apply distinct environmental standards in their countries of origin and there or is their operational bases ${ }^{4}$.

This report shows that most of the environmental disasters are committed on the soil of a country with a weak legal and institutional system. It follows that it is quite difficult to implement the environmental responsibility of multinationals, if always certain states are recessed with regard to the evolutions in international environmental law.

The uncertainty of the effectiveness of this right by the different actors of international law arises from the complexity of the legal framework in this field : between international standards, community, national and multinational flexibility to use non-binding instruments such as Soft law or the Global Compact (UN Global Compact) ${ }^{5}$.

This internal self-regulation strategy through social and environmental responsibility is a voluntary process that the company intends to comply with recognized by international instruments such as the Universal Declaration of Human Rights universal principles, the principles of Organisation for economic Cooperation and development and the International Labour Organisation which the right of the environment is a part. The sanctions of this latter approach stems rarely of regimes of legal responsibility but mechanisms and social behaviors that are as much incentives for multinationals to integrate environmental concerns in its activities ${ }^{6}$. In the absence of well established legal commitments, once again international law feels its impropriety in front of instruments « responsible » for moral order.

In quantitative terms, international environmental law has a considerable number of conventions ratified by the states. But beyond this willingness, the transposition and application of international standards for domestic laws raise inconsistencies. Internally, the practice of legal redress environmental damage of some use, as evidenced by examples of ecological disasters in recent decades. Therefore, some judicial decisions have been highly acclaimed by the public (Red Sludge affair of Montedison in 1976, of the Erika in 1999, and of the Prestige in 2001) ${ }^{7}$

Nevertheless, it must still emphasize that internationally the Alien Tort Claims Act (ATCA) in the United States remains the only instrument to judge civilly multinationals because of violations of the right to environment. Indeed, the affair Doe v. Unocal has a major advantage because it assimilates the environmental damage to violations of human rights without taking into account the nationality or status of the person allegedly responsible (States or their agents, multinationals) and the place environmental damage have been produced. Since then, the ATCA has increased requests for several multinationals (Coca Cola, Texaco, Riotinto, etc.). However, in spite of a large number of affairs brought before U.S. courts against multinational no case has led to this day at the same ability to hold the moral persons s responsible for a violation of the right of environment. Despite several attempts by non-governmental organizations to provide an international legal response to the impunity of multinational, no international convention on the subject is directly binding today ${ }^{8}$.

\section{The uncertain but necessary recognition of collective penal responsibility of the multinational}

The irresponsibility of multinationals appears vividly especially for subsidiaries in some countries of Africa and Latin America. The affairs brought against multinational generally result in settlement agreements. If these agreements provide financial compensation to victims, it remains that the repair of environmental damage remains the poor relation because multinationals are in principle exempt from any liability.

Unexpectedly, even paradoxical, it is the law of the environment that could be the engine of essential changes in the legal regime of corporate groups. Admittedly, the thought could be pushed to possible recognition in environmental matters, the economic unity of the group through the paradigm of the company. It is not permissible that a parent company is not liable for offenses against the environment by its subsidiaries?.

The group is a limited technique of responsability organized around the principle of legal independence of companies (eg the Bhopal affair in India). Two issues that cross all thoughts on the subject seem us to deserve to be included : why international environmental law should recognize legally the collective penal responsability of parent companies? And how is it possible to implement it? The answers to all these questions regularly headlines in the news especially when the subsidiary after the end of the operation leaves the natural environment in a state of destruction or intolerable pollution.

\footnotetext{
${ }^{4}$ Martin A. N., Elément pour un droit pénal de l'environnement, Revue de science criminelle, 2012, p. 69.

${ }^{5}$ Mongin J., Le droit pénal demeure-t- étranger à la notion de « développement durable » ? Rien n'est moins sûr ! AJ Pénal, 2009 , p. 402.

${ }_{7}^{6}$ Kromarek P., L'actualité de la responsabilité environnementale de l'entreprise, Environnement n ${ }^{\circ} 10$, Octobre 2006 , p. 13.

${ }^{7}$ Huglo C., La réparation des dommages écologiques: Entre discussions de principe, transposition incomplète du droit communautaire et apport constant de la jurisprudence, Gazette du palais $\mathrm{n}^{\circ} 356,22$ décembre 2007, p. 5. Cf. Marguenaud J-P., L'adaptation des garanties procédurales européennes aux exigences de la répression des délits contre l'environnement : CEDH 8 janvier 2009, 3 section, Mangouras c/ Espagne, Revue de science criminelle, 2009, p. 180.

${ }^{8}$ Mauro C., Application dans l'espace de la loi pénale et entreprises multinationales, AJ Pénal, 2012, p. 12.

${ }^{9}$ Grimonprez B., Pour une responsabilité des sociétés mères du faits de leurs filiales, Revue des sociétés, 2010 , p. 715.
} 
Multinationals as agents of globalization are not subjects of international law and consequently this group of companies has no international legal personality. Thus, despite a reflection in the negotiations about the possible jurisdiction of the International Criminal Court towards the moral persons, the Rome Statute does not provide the sole responsibility of individuals « Societas delinquere non potest $»^{10}$.

The extension of the scope of application of international penal law on the principle of universal jurisdiction in some serious environmental offenses could be a solution to deter multinationals. Would still have to define these environmental crimes (ecocide, géocide, patrimonicide). In the absence of an international penal responsability of the moral persons, international conventions designed to protect the environment commit only States to set up an efficient legal arsenal. However, in reality, and until now a lot of business bounce demonstrating, either the weakness of the existing legal systems, or the complicity of some government leaders with some multinationals (eg Somalia, Gabon).

Pending the development of international penal law of environment to directly reach multinationals, several scenarios are possible. The objective is to establish an effective allocation system of the offense to the environment to parent companies by granting jurisdiction to the penal jurisdiction of the State of the head office. The first already has its origin in the law of the European competition. The Court of Justice of the European Union ruled that : " the conduct of a subsidiary may be imputed to the parent company in particular where, although having a separate legal personality, that subsidiary does not decide independently upon its own conduct on market but carries out, the instructions given to it by the parent company ${ }^{11}$.

In the same vein, the Erika case is similar to the case cited above. Rightly, the Paris Court of Appeal dismissed the penal reponsability of the subsidiary in favor of that of the parent company (French oil group «Total») after finding that in fact it was the parent company which exercised a power of control : « ... the subsidiary had no strength, no local in Panama where she was registered [...], no legal or financial autonomy... $»^{12}$. Such reasoning can it be transferred to other countries especially in the macro-environmental damage? It is fairly difficult to open this gap since it disregards the financial autonomy of the companies and the limitation of liability that are entitled corporations. In addition, this possibility is not enough when there are problems of judicial cooperation between the state of the head office of the parent company and the jurisdiction of the state where ecological damage has occurred since this procedure is designed as an attack on its sovereignty.

Another solution already adopted by OECD countries to fight against international corruption of public officials can be effective if it is introduced into domestic legislation. It involves applying the principle of active personality in order to achieve multinationals independently of countries where they operate. The extension of extraterritorial jurisdiction to hazardous environmental damage overcomes the inaction of some countries to establish penal reponsability through judicial implementation.

This personal skill is nevertheless subject to many conditions that should be dictated by considerations of transparency. It is sufficient that the competent authorities of the place of ecological disaster do not occur or they trigger prosecution " of convenience ", to escape prosecution. In addition, it is quite difficult to punish lawful conduct carried out on the territory of another country.

\section{Conclusion}

Far from the catastrophic performances, it would be foolhardy to try to draw conclusions about the inherent problems in the implementation of environmental responsibility of multinationals. It seems that the current debates on the legal improvement of the environment converge to give rise to ambitious doctrinal projects advocating a broader responsibility of the parent companies. However, this involvement would establish undeniably a cornerstone in the status of bioactor company.

\section{References}

[1] Addan Nieto Martin, Elément pour un droit pénal de l'environnement, Revue de science criminelle, 2012.

[2] Antoine Bernard, Elin Wrzoncki, La responsabilité pénale des transnationales-L'action de la FIDH, AJ Pénal, 2012.

[3] Benoît Grimonprez, Pour une responsabilité des sociétés mères des faits de leurs filiales, Revue des sociétés, 2010.

[4] Caroline London, L’environnement, une nouvelle donne économique, Petites affiches n 78, 30 juin 1995.

[5] Christian Huglo, La réparation des dommages écologiques: Entre discussions de principe, transposition incomplète du droit communautaire et apport constant de la jurisprudence, Gazette du palais n 356, 22 décembre 2007.

[6] Cristina Mauro, Application dans l'espace de la loi pénale et entreprises multinationales, AJ Pénal, 2012.

[7] Emmanuel Daoud, Annaelle ANDRE, La responsabilité pénale des entreprises transnationales françaises : fiction ou réalité juridique? AJ Pénal, 2012.

\footnotetext{
${ }^{10}$ Daoud E., Andre A., La responsabilité pénale des entreprises transnationales françaises : fiction ou réalité juridique ? AJ Pénal, 2012, p. 15 .

${ }^{11}$ Translation from : Décision de la CJCE du 10 septembre 2009, Affaire n ${ }^{\circ} \mathrm{C}-97 / 08$, Akzo Nobel NV c/ Commission, $\$ 58$.

12 Arrêt de la Cour d'appel de Paris du 20 mars 2010, Affaire Erika. La Chambre criminelle de la Cour de cassation française a récemment confirmé l'arrêt de la même Cour, Arrêt n 3439 du 25 septembre 2012 (10-82.938).
} 
[8] Jean-Pierre Marguenaud, L'adaptation des garanties procédurales européennes aux exigences de la répression des délits contre l'environnement. CEDH 8 janvier 2009, 3 section, Mangouras c/ Espagne, Revue de science criminelle, 2009.

[9] Juliette Mongin, Le droit pénal demeure-t- étranger à la notion de «développement durable »? Rien n'est moins sûr! AJ Pénal, 2009.

[10] Marie-Pierre Blin-franchomme, De l'évolution des espèces : vers une responsabilité environnementale des groupes de sociétés, Bulletin du droit de l'environnement industriel $\mathrm{n}^{\circ}$ 24, 01/11/2009.

[11] Pascale Kromarek, L'actualité de la responsabilité environnementale de l'entreprise, Environnement n 10, Octobre 2006.

[12] Peter Herbel, La justice est-elle un nouveau risque ? Droit et patrimoine $n^{\circ} 124,2004$.

[13] Yves Jegouzou, Propriété et environnement, Defrénois nº 7, 15 avril 1994. 